\title{
A bacteriolytic muramidase from the basidiomycete Schizophyllum commune
}

\author{
W. D. Grant, ${ }^{*}$ B. A. Prosser and R. A. Asher \\ Cawthron Institute, Private Bag, Nelson, New Zealand
}

(Received 19 March 1990; revised 4 July 1990; accepted 11 July 1990)

\begin{abstract}
The basidiomycete Schizophyllum commune produces an extracellular bacteriolytic enzyme when grown on heatkilled cells of Bacillus subtilis as sole $\mathbf{C}, \mathbf{N}$ and $\mathbf{P}$ source. The enzyme catalyses the dissolution of isolated $B$. subtilis cell walls at an optimum $\mathrm{pH}$ of $3 \cdot 2-3 \cdot 4$, releasing muramyl reducing groups, which indicates that it is a muramidase. Although low levels of enzyme activity are present when the fungus is grown in the absence of bacteria, full enzyme production appears to be induced by bacterial cells and repressed by glucose. Whole bacteria are not lysed by the enzyme at pH 3.3, but are rendered osmotically fragile, and lyse when the pH is raised to 7 or higher. The muramidase is effective against several Gram-positive bacteria but did not lyse any of the Gramnegative species tested.
\end{abstract}

\section{Introduction}

Fermor \& Wood (1981) found that several basidiomycetes were well suited to growth on bacterial cells as a substrate and that Schizophyllum commune was one of the most vigorous colonizers of heat-killed Bacillus subtilis cells in solid media. This work was confirmed recently (Grant et al., 1986) when it was shown that S. commune, in common with other fungi, was able to grow in liquid culture at the expense of heat-killed cells or isolated cell walls of $B$. subtilis in buffered mineral media. The cells or walls were extensively degraded as fungal growth took place and wall-degrading enzyme activity was detected in the culture fluids. Out of 12 fungi chosen for their ability to synthesize such enzymes, $S$. commune produced the most effective bacteriolysis, judged on the joint criteria of rate of dissolution of buffered wall suspensions and extent of lysis of bacteria in the fungal cultures. The enzyme responsible was shown to be a glycosidase with a pH optimum of 3.2-3.4 (Grant et al., 1986). In this investigation we describe the production and properties of this enzyme: it is an extracellular muramidase capable of lysing the walls of several Gram-positive species, and is produced when bacterial cells are present in the fungal growth medium. The enzyme is of potential importance in comparative studies on the active sites of polysaccharide hydrolases (Yaguchi et al., 1983).

Abbreviation: HEWL, hen egg-white lysozyme.

\section{Methods}

Organisms. Schizophyllum commune strain 59A was obtained from the culture collection of the Forest Research Institute, Rotorua, New Zealand. Bacillus subtilis 168, obtained from the Microbiology Unit, University of Oxford, UK, was used as a fungal growth substrate, and walls from this organism were used in the assay of wall-lytic enzymes (Grant et al., 1986). With the exceptions of Bacillus stearothermophilus B65 and B. subtilis W23, which were from our laboratory stock, all bacteria were numbered strains from recognized culture collections (see Table 1).

Bacterial cultures. All bacteria were grown in Nutrient Broth (Oxoid) with the exception of the lactobacilli and streptococci, which were cultured on Lactobacilli MRS Broth (Difco). Cultures were grown to mid-exponential phase, harvested by centrifugation, washed with distilled water, then used as substrate in the bacteriolytic enzyme assay. Cells of $B$. subtilis 168 for use as fungal growth substrate were heatkilled $\left(100^{\circ} \mathrm{C}, 15 \mathrm{~min}\right)$, washed once with distilled water, then freezedried from distilled water suspension.

Bacterial cell walls. Cell walls were prepared from mid-exponential phase cultures of B. subtilis 168 by breakage of the cells in a Braun MSK homogenizer and purification by the procedure of Anderson et al. (1978), in which autolytic enzymes are denatured during treatment with SDS at $100^{\circ} \mathrm{C}$.

Fungal cultures. S. commune was grown statically at $25^{\circ} \mathrm{C}$ on (i) Sabouraud's liquid medium (SL) (Oxoid) at pH 5 with $0.4 \mu \mathrm{M}$-thiamin and $0.04 \mu \mathrm{M}$-biotin supplements, (ii) a defined glucose/salts medium (GS) containing $\mathrm{KH}_{2} \mathrm{PO}_{4}, 7.4 \mathrm{mM} ; \mathrm{NH}_{4} \mathrm{NO}_{3}, 12.5 \mathrm{mM} ; \mathrm{MgSO}_{4}$, $2 \mathrm{mM} ; \mathrm{CaCl}_{2}, 2 \mathrm{mM} ; \mathrm{H}_{3} \mathrm{BO}_{3}, 46 \mu \mathrm{M} ; \mathrm{MnCl}_{2}, 9 \mu \mathrm{M} ; \mathrm{ZnCl}_{2}, 0.73 \mu \mathrm{M}$; $\mathrm{CuSO}_{4}, 0.32 \mu \mathrm{M} ;\left(\mathrm{NH}_{4}\right)_{6} \mathrm{Mo}_{7} \mathrm{O}_{24}, 0.032 \mu \mathrm{M} ; \mathrm{D}$-glucose, $0.1 \mathrm{M}$; thiamin, $0.4 \mu \mathrm{M}$; biotin, $0.04 \mu \mathrm{M}$; buffered with $0.05 \mathrm{M}$-MES to $\mathrm{pH} 5$, and (iii) a bacteria/salts medium (BS) which was GS medium with glucose, $\mathrm{KH}_{2} \mathrm{PO}_{4}$ and $\mathrm{NH}_{4} \mathrm{NO}_{3}$ omitted and replaced by heat-killed freezedried B. subtilis cells $\left(2.5 \mathrm{mg} \mathrm{ml}^{-1}\right)$ as $\mathrm{C}, \mathrm{P}$ and $\mathrm{N}$ source. Starter cultures ( $10 \mathrm{ml}$, GS medium) were inoculated from potato dextrose agar 
plates, incubated for $4 \mathrm{~d}$, harvested, and washed with sterile GS salts (GS medium with glucose, $\mathrm{KH}_{2} \mathrm{PO}_{4}$ and $\mathrm{NH}_{4} \mathrm{NO}_{3}$ omitted). Mycelium was fragmented with glass beads on a wrist-action shaker and used to inoculate experimental growth flasks.

Harvesting and biomass estimation. In quantitative growth and enzyme production experiments, duplicate $25 \mathrm{ml}$ cultures were harvested by centrifugation $(5000 \mathrm{~g}, 15 \mathrm{~min})$ at $24 \mathrm{~h}$ or $48 \mathrm{~h}$ intervals. Pellets were washed once with distilled water. The wash was combined with the original supernatant and made up to a known volume before filtering $(0.45 \mu \mathrm{m})$ and freezing. Pellets were dried $\left(105^{\circ} \mathrm{C}\right)$ to constant weight, or freeze-dried if fungal biomass was to be measured by ergosterol extraction and estimation. For the latter method, a modification of the procedure of Seitz et al. (1979) was used. Mycelium was homogenized in an Ultraturrax homogenizer $(3 \times 30 \mathrm{~s}$ bursts $)$ in cold methanol $(25 \mathrm{ml}$ ), filtered (Whatman GFC paper), then washed with methanol $(2 \times 5 \mathrm{ml})$. The filtrate was made up to $40 \mathrm{ml}$ with methanol then saponified by refluxing for $30 \mathrm{~min}$ with $\mathrm{KOH}(4 \mathrm{~g})$ and ethanol $(10 \mathrm{ml})$. After addition of water $(10 \mathrm{ml})$ to the cooled solution, ergosterol was extracted with $3 \times 25 \mathrm{ml}$ redistilled hexane. The combined extracts were rotary evaporated $\left(30-35^{\circ} \mathrm{C}\right)$ to dryness, dissolved in methanol $(5.0 \mathrm{ml})$ then passed through a $0.2 \mu \mathrm{m}$ Teflon filter (Gelman Acrodisc CR). Ergosterol was measured by HPLC on a Waters $\mu$ Bondapak C-18 column, eluted with methanol/water $(95: 5$, $\mathrm{v} / \mathrm{v}$ ) at a flow rate of $2 \mathrm{ml} \mathrm{min}^{-1}$, measuring absorbance at $282 \mathrm{~nm}$. Mycelial ergosterol contents were calibrated against dry weight measurements of $S$. commune after different periods of growth in GS medium. The linear relationship obtained was used to estimate fungal biomass in BS cultures, where bacterial cells and cell debris precluded measurement by direct weighing.

Enzyme assays and analytical methods. Wall-degrading enzyme activity was assayed by measuring the rate of decrease of optical density $\left(\Delta O D_{600} h^{-1}\right)$, over several hours, of a mixture containing $B$. subtilis walls $(600 \mu \mathrm{g})$ suspended in buffer to a final volume of $310 \mu \mathrm{l}$, and culture supernatant $(100 \mu \mathrm{l})$ incubated at $25^{\circ} \mathrm{C}$ (Grant et al., 1986). One unit is defined as the quantity of enzyme in $100 \mu$ of supernatant catalysing a $\Delta \mathrm{OD}_{600}$ of 1.0 in $1 \mathrm{~h}$ under the assay conditions. Culture filtrates were concentrated where necessary by ultrafiltration (Amicon YM-10 membrane). The $\mathrm{pH}$ optimum of wall-degrading activity in culture supernatants was determined by assaying over the $\mathrm{pH}$ range 2.5-9.8 using sodium formate/formic acid (2.5-4.8), sodium acetate/

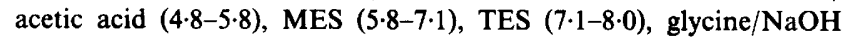
(8.5-9.4), and $\mathrm{NaHCO}_{3} / \mathrm{NaOH}(9 \cdot 4-9.8)$ buffers, all at ionic strength 0.05 .

Bacteriolytic enzyme activity, i.e. lysis of whole bacterial cells, was assayed by incubating suspensions of freshly-grown bacteria in formate buffer (ionic strength $\mathbf{0 . 0 2 5}$ ) with culture supernatant or supernatant concentrates at $25^{\circ} \mathrm{C}$. Samples $(2 \times 100 \mu l)$ were transferred at intervals into $200 \mu 10.5 \mathrm{M}$-TES buffer $\mathrm{pH} 8.6$ and $200 \mu \mathrm{l}$ of the formate buffer (control) and the $\mathrm{OD}_{600}$ values of both were read $5 \mathrm{~min}$ after transfer. Control experiments in which the bacteria were incubated with GS salts instead of culture supernatant were performed for each bacterial species, with aliquots being transferred to the two buffers at appropriate intervals in each case. Optical density changes caused by autolysis or dilution effects were corrected using the results from the controls.

Glucose was measured with a commercial glucose oxidase analytical kit (Tekit 952 DM, Searle Diagnostics).

Reducing groups released by the action of enzyme on cell walls were measured by the method of Park \& Johnson (1949). Reducing terminal residues were identified and estimated by two-dimensional paper chromatography as previously described (Grant et al., 1984) after $\mathrm{NaBH}_{4}$ reduction and acid hydrolysis (Ghuysen et al., 1966).

\section{Results}

Growth of S. commune and production of wall-degrading enzyme

Extracellular bacterial wall-degrading activity was produced by $S$. commune when it was grown at either pH 7 or pH 5 on heat-killed $B$. subtilis cells as sole $\mathrm{C}, \mathrm{N}$ and $\mathrm{P}$ source, although higher activity was consistently obtained at the lower $\mathrm{pH}$. Quantitative growth studies and enzyme activity measurements were carried out on cultures of this fungus at $\mathrm{pH} 5$ and $25^{\circ} \mathrm{C}$ in the three different media: BS, a suspension of heat-killed B. subtilis cells in mineral salts; GS, a glucose/salts medium, and SL, a glucose/peptone broth (Fig. 1). The specific activities per $\mathrm{mg}$ fungal dry weight are shown in Fig. 2.

\section{Properties of wall-degrading enzyme}

The $\mathrm{pH}$ optimum of $3 \cdot 2-3 \cdot 4$ reported for the wall-lytic activity in $S$. commune culture fluids after growth on B. subtilis (Grant et al., 1986) was confirmed. The $\mathrm{pH}$ profiles of the enzymes present in supernatants from SL and GS cultures were similar to that in the BS culture fluids, with optima at $\mathbf{p H} 3 \cdot 2-3 \cdot 3$.

Hydrolysis of $B$. subtilis walls by $S$. commune culture supernatants was accompanied by the release of reducing groups but not amino groups (Grant et al., 1986). The time course of appearance of reducing groups is shown in Fig. 3. Duplicate determinations of the muramic acid residues susceptible to $\mathrm{NaBH}_{4}$ reduction after wall digestion with $S$. commune supernatant showed that a mean of $70 \%$ (individual determinations $63 \%$ and $77 \%$ ) possessed free reducing groups, whereas $<10 \%$ (individual determinations $0 \%$ and $16 \%$ ) of the wall glucosamine residues were available for $\mathrm{NaBH}_{4}$ reduction. This indicated that the enzyme activity was that of a muramidase, and this was confirmed by the detection of muramicitol but not glucosaminitol on paper chromatograms of acid hydrolysates of the reduced wall digests. In addition, the concentrated culture fluids did not catalyse the hydrolysis of the $\beta-N$-acetylglucosaminidase substrate 4-nitrophenyl- $N$-acetyl- $\beta$-D-glucosaminide (Maruhn et al., 1976).

\section{Control of synthesis of the wall-degrading enzyme}

The results in Figs 1 and 2 indicated that the enzyme was probably induced by the presence of bacterial cells. When a culture of $S$. commune in GS medium was supplemented with heat-killed $B$. subtilis (final concentration $2.5 \mathrm{mg} \mathrm{ml}^{-1}$ ) after several days' growth, wall- 


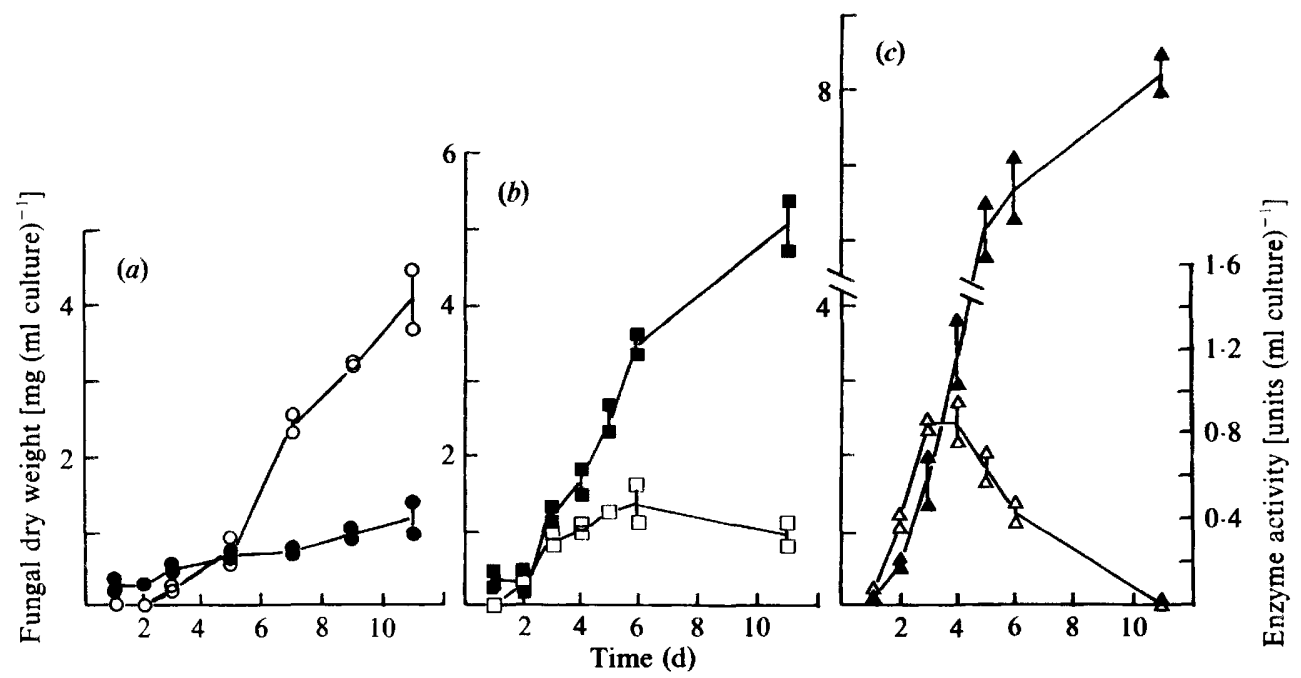

Fig. 1. Fungal dry weight (filled symbols) and extracellular wall-degrading enzyme activity (open symbols) of $S$. commune grown in (a) Bacillus subtilis (BS), (b) glucose/salts (GS), and (c) Sabouraud's liquid (SL) media. Duplicate cultures in each medium were harvested daily in the early part of the growth period, then less frequently. Fungal dry weights in (a) were obtained from a calibration curve relating dry weight to mycelial ergosterol content. Note the interrupted dry weight scale in $(c)$.

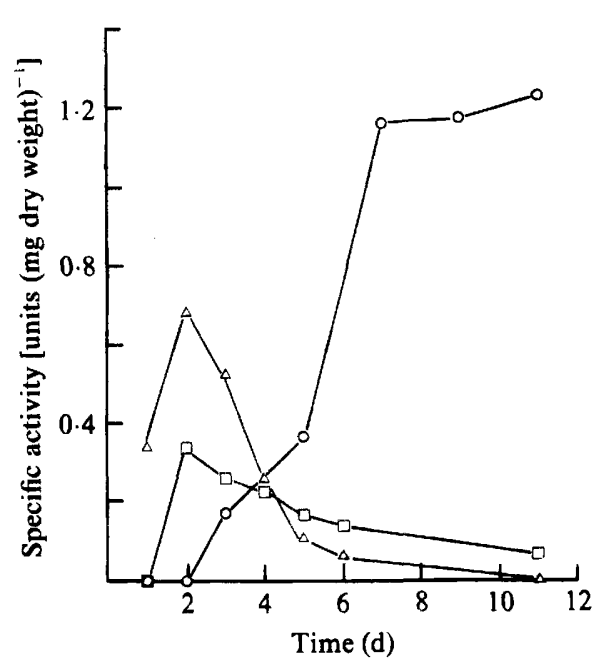

Fig. 2. Specific activities of wall-degrading enzyme in cultures of $S$. commune grown in BS $(O)$, GS $(\square)$ and SL $(\triangle)$ media (see Fig. 1). Data are means of specific activities of the duplicate cultures.

degrading activity was higher than that of an unsupplemented control culture. Although the extent of increased enzyme production varied considerably in such cultures, high levels of activity were consistently produced in response to addition of bacterial cells when the glucose in the medium was replaced with glycerol. Fig. 4 shows one of three similar experiments in which wall-lytic enzyme activity appeared in response to the addition of heatkilled bacteria. Increased activity was never detected in the unsupplemented control cultures. The final enzyme activity in the supplemented cultures varied from $0 \cdot 10$ to $0 \cdot 17$ units.

In other experiments, glucose was added (final concentration $20 \mathrm{mg} \mathrm{ml}^{-1}$ ) to cultures of the fungus growing on heat-killed bacteria (BS medium) (Fig. 5). Glucose addition at day 3 delayed the appearance of wall-degrading activity in the culture fluid until the glucose had been utilized. Essentially the same results were obtained when glucose was added at day 0 (not shown). However, addition at day 6, when appreciable levels of activity were already present, did not prevent further increase in activity with time.

\section{Enzyme action on whole bacteria}

$S$. commune culture fluids which would rapidly degrade isolated $B$. subtilis walls were unable to lyse suspensions of the live bacteria at $\mathrm{pH} 3 \cdot 3$. Prolonged incubation of cells with 20 -fold concentrates of such culture fluids had only very slight effects on the optical density of the suspension. Microscopic examination of the treated bacteria, however, showed that although individual cells were intact and indistinguishable in appearance from normal B. subtilis, virtually all of the typical exponentialphase filaments of the bacteria had been converted to single cells. It was subsequently discovered that these cells lysed instantly on addition of dilute alkali, and it seems likely that at least some of the cell wall had been removed by the action of the enzyme. Thus, to measure the action of $S$. commune culture fluids against whole bacteria, it was necessary to incubate at low $\mathrm{pH}$ then to 

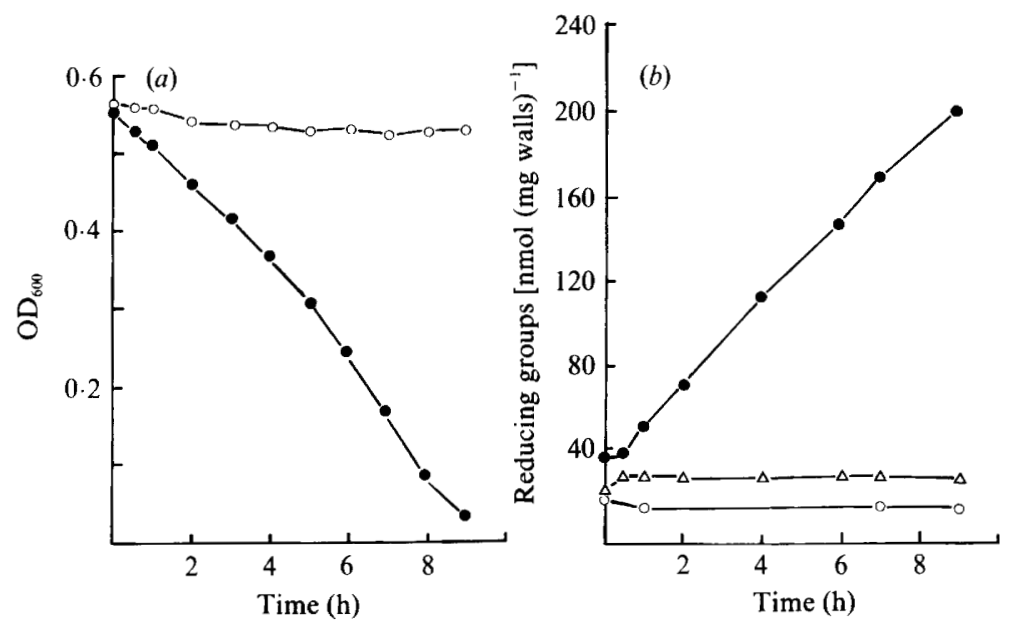

Fig. 3. Time course of lysis of $B$. subtilis cell walls by $S$. commune culture fluid. (a) Optical density of cell wall suspension; $(b)$ increase in reducing groups during cell wall dissolution. Data points represent means of duplicate determinations. Variation between duplicates was less than $\pm 5 \%$. , Walls plus culture fluid; $O$, walls plus $\mathrm{BS}$ medium base; $\Delta$, culture fluid alone.

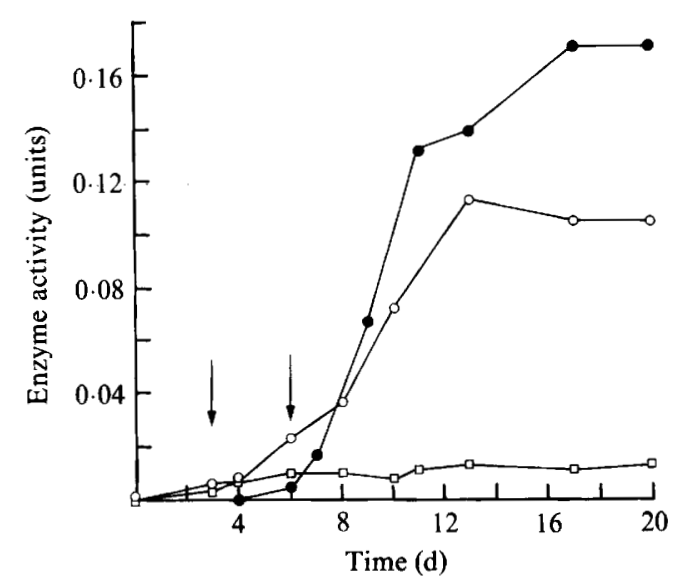

Fig. 4. Wall-degrading activity in cultures of $S$. commune on addition of heat-killed B. subtilis cells $\left(2.5 \mathrm{mg} \mathrm{m}^{-1}\right.$ final concentration) after $3 \mathrm{~d}$ $(O)$ and $6 \mathrm{~d}(\bullet)$ growth on GS medium in which glucose was replaced by glycerol as carbon source. $\square$, Unsupplemented control culture. Data points represent single determinations of enzyme activity in culture fluid samples. Arrows, points of addition of bacterial cells.

transfer samples at intervals to an alkaline buffer before measuring optical density. Controls were samples diluted identically in the incubation buffer. Identical experiments in which GS salts were used in place of the fungal culture fluid produced no loss of optical density at either $\mathrm{pH}$ over several hours. The most rapid lysis of $B$. subtilis occurred when the $\mathrm{pH}$ of the incubation buffer was 3.8 .
Twenty-seven bacterial strains were tested in this way for their susceptibility to the action of $S$. commune culture fluid (Table 1). Where activity was low or absent, the experiment was repeated using a 20 -fold concentrate of the culture fluid.

Table 1. Lysis of bacteria by $S$. commune culture fluid

\begin{tabular}{|c|c|}
\hline Organism & Relative lytic activity* \\
\hline Arthrobacter citreus NCIB 8915 & 3 \\
\hline A. globiformis NCIB 8602 & 76 \\
\hline A. globiformis NCIB 7811 & 0 \\
\hline Bacillus cereus NCTC 8035 & 28 \\
\hline B. licheniformis NCTC 6346 & 72 \\
\hline B. megaterium NCTC 10342 & 57 \\
\hline B. pumilus NCTC 8241 & 152 \\
\hline B. stearothermophilus B65 & 57 \\
\hline B. subtilis 168 & 100 \\
\hline B. subtilis ATCC 6633 & 170 \\
\hline B. subtilis W23 & 45 \\
\hline Brevibacterium albidum ATCC 15831 & 0 \\
\hline Corynebacterium aquaticum NCIB 9460 & 0 \\
\hline Enterobacter aerogenes NCTC 10006 & 0 \\
\hline Escherichia coli NCTC 8196 & 0 \\
\hline Lactobacillus bulgaricus NCDO 1489 & 28 \\
\hline L. casei ATCC 7469 & 0 \\
\hline L. plantarum ATCC 8014 & 79 \\
\hline Micrococcus luteus NCTC 2665 & 13 \\
\hline Proteus vulgaris NCTC 4635 & 0 \\
\hline Pseudomonas aeruginosa NCTC 6749 & 0 \\
\hline Serratia marcescens NCTC 10211 & 0 \\
\hline Staphylococcus aureus NCTC 4163 & 0 \\
\hline Staph. epidermidis ATCC 14990 & 45 \\
\hline Streptococcus faecium NCTC 7171 & 4 \\
\hline Strep. lactis NCTC 6681 & 2 \\
\hline Strep. salivarius ATCC 13419 & 0 \\
\hline
\end{tabular}

* Activity against B. subtilis 168 set at 100 . 


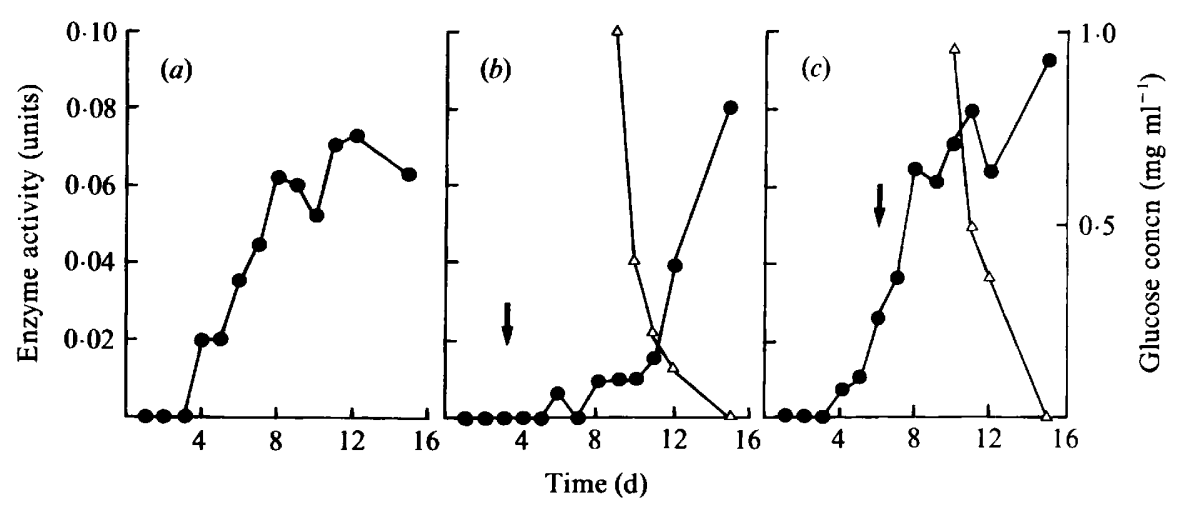

Fig. 5. Effect of addition of glucose $\left(20 \mathrm{mg} \mathrm{m}^{-1}\right.$, final concentration) on production of wall-degrading activity by cultures of S. commune growing on BS medium. (a) Control culture; (b) glucose added at day 3 (arrow); (c) glucose added at day 6 (arrow). $\bullet$, Walldegrading activity (data points are single determinations of enzyme activity in culture fluid samples); $\triangle$, glucose concentration in culture fluid (means of duplicate determinations: variation between duplicates less than $\pm 5 \%$ of the mean).

\section{Discussion}

When $S$. commune was grown on a medium containing heat-killed $B$. subtilis cells as sole $\mathrm{C}, \mathrm{N}$ and $\mathrm{P}$ source, an extracellular enzyme activity was produced which degraded the bacteria and which could also catalyse the dissolution of isolated B. subtilis cell walls (Fermor \& Wood, 1981; Grant et al., 1986). Cell wall hydrolysis was accompanied by the release of free reducing groups but no amino groups (Grant et al., 1986). Since we have now shown that $90 \%$ of the released reducing groups were muramic acid residues, and that the culture filtrates of the fungus contained no $\beta$ - $N$-acetylglucosaminidase activity, we conclude that the enzyme is a muramidase or 'lysozyme', viz. a hydrolase specific for the muramyl glycosidic linkage in the cell wall peptidoglycan. As this linkage occurs only in bacterial or endospore wall structures, it seems likely that the enzyme is produced by the fungus as part of a specific mechanism for degradation of bacterial cells. We have recently confirmed that the enzyme is also produced when the fungus grows at the expense of viable bacteria (W. D. Grant, unpublished results), although the interfering effects of bacterial autolysis make this unsuitable as an experimental system.

Many microbial muramidases are optimally active in acid conditions (e.g. Hash, 1963; Morita et al., 1978; Hayashi et al., 1984), but the $\mathrm{pH}$ optimum of 3.3 for the $S$. commune enzyme is surprisingly low. This characteristic could provide a test of the accepted muramidase mechanism, as exemplified by hen egg-white lysozyme (HEWL). The HEWL active site contains two residues, Glu-35 and Asp-52, which are essential for activity, with Glu-35 in the protonated and Asp-52 in the ionized form
(Blake et al., 1967), and although the muramidase from the fungus Chalaropsis appears to have analogous catalytic residues (Fouche \& Hash, 1978) its $\mathrm{pH}$ optimum (4.6) is higher than that of the $S$. commune enzyme. An acidic residue with an unusually low pK would be required to allow maximal activity at pH 3.3. Although Rupley et al. (1974) showed that the pK of Asp-52 in HEWL could be as low as $3 \cdot 8$, it is clear that a study of the active site of the $S$. commune enzyme could provide further insights into muramidase mechanism(s). Such a study would also be of interest because of the known homology between the active sites of endoglucanases from this fungus and that of HEWL (Yaguchi et al., 1983; Paice et al., 1984). It is interesting in this regard that one of these $S$. commune endoglucanases possesses a glutamic acid residue at position 33: Glu-33 is thought to be part of the active site of the muramidase from Chalaropsis (Fouche \& Hash, 1978).

The specific activity of the wall-degrading enzyme from $S$. commune grown on peptone-containing medium with high levels of glucose (SL medium) was greater than that obtained from growth on a defined glucose/salts (GS) medium (Fig. 2). This result parallels the findings of Hash (1963) and Hash \& Rothlauf (1967) with Chalaropsis, and the synthesis of other bacteriolytic enzymes appears to be enhanced by growth of the producing organism in rich media (e.g. Imada et al., 1973; Yokogawa et al., 1973; Hayashi et al., 1983). Although the high activity in $S$. commune broth cultures was rapidly lost as the cultures aged, this could have resulted from the action of proteases which are produced under these growth conditions (W. D. Grant, unpublished results). However, in contrast to other bacteriolytic enzyme systems (Ward \& Perkins, 1968; Hash, 1974), 
much higher and more stable activities were obtained with a bacterial substrate (Figs 1 and 2), and addition of bacteria to glycerol-grown $S$. commune resulted in increased enzyme activity (Fig. 4). It therefore seems probable that bacteria or bacterial cell components are able to induce synthesis of this enzyme, although the results with SL medium indicate that the induction mechanism is not specific to these components. Glucose repression of enzyme production was indicated by the fact that glucose addition at early stages of growth delayed the appearance of the enzyme activity in BS cultures until after the sugar had been utilized by the fungus (Fig. 5). Although glucose additions after enzyme activity had begun to appear did not prevent further increases in activity (Fig. $5 c$ ), it is possible that repression of enzyme synthesis was masked by continued release of enzyme from its binding to the bacterial substrate (Grant et al., 1986). Glucose repression may also be implicated in the inconsistent levels of enzyme activity produced when bacteria were added to glucosegrown cultures.

The failure of $S$. commune culture fluids to lyse viable bacteria at the $\mathrm{pH}$ optimum of wall-degrading activity was not unexpected. Hash (1963) found that the $\mathrm{pH}$ optimum of the Chalaropsis enzyme was 4.6 for cell walls of Staphylococcus aureus, but 5.6 for whole cells, although the latter was dramatically affected by the ionic strength of the buffer used. Other workers have reported similar differences in $\mathrm{pH}$ optima for bacteriolytic enzyme activity against whole cells or cell walls (Ward \& Perkins, 1968; Yokogawa et al., 1975), and difficulties with reproducibility of lysis of whole cells with the Chalaropsis enzyme led Hash (1967) to publish a bacteriolysis assay procedure with buffered suspensions of isolated walls as substrate. Preliminary experiments with the $S$. commune culture fluids showed that there was an apparent $\mathrm{pH}$ optimum for whole cell lysis of $6 \cdot 0-6 \cdot 2$, but it was soon discovered that this represented a balance between the action of the enzyme in degrading the walls at a low $\mathrm{pH}$ (optimum 3.8) and that of the surrounding medium in effecting osmotic lysis of the resulting spheroplasts (optimum pH >7). Further investigation of the enzymetreated cells has shown that they are indeed protoplasts, which are osmotically stable at pH 3-4 (W. D. Grant, unpublished results). Cell damage by lysozyme at acid $\mathrm{pH}$ followed by lysis in alkali was first discovered in Escherichia coli by Nakamura (1923), and demonstrated in other bacteria by Grula \& Hartsell $(1954,1957 a, b)$. The relative stability of protoplasts and spheroplasts to osmotic effects at low $\mathrm{pH}$ has been described previously (Edebo, 1961; Op den Kamp et al., 1967; van Iterson \& Op den Kamp, 1969; Wecke et al., 1982).

The results in Table 1 indicate that, as with other muramidases, the $S$. commune enzyme is active against several Gram-positive bacteria, the bacilli in particular, but is not effective in lysing Gram-negative species. It is interesting that Micrococcus luteus, which is extremely sensitive to lysis by HEWL, is only slowly attacked by the $S$. commune enzyme. The range of bacteria sensitive to the enzyme is similar in some respects to that of the now commonly-used bacteriolytic preparation, mutanolysin, from Streptomyces globisporus (Yokogawa et al., 1973,1974 ), although the $S$. commune enzyme appears to be less effective on the species of Lactobacillaceae tested. This and other fungal muramidases may well be of value in applications which call for low $\mathrm{pH}$ conditions, and in this regard could be important as preserving agents in certain foods (Hughey \& Johnson, 1987).

We thank Professor Margaret Loutit, Microbiology Department, University of Otago, Dunedin, New Zealand, and Dr Patrick Piggot, Department of Microbiology and Immunology, Temple University School of Medicine, Philadelphia, USA, for their generous gifts of bacterial cultures.

The New Zealand Government research grant to Cawthron Institute is gratefully acknowledged.

\section{References}

Anderson, A. J., Green, R. S., Sturman, A. J. \& Archibald, A. R. (1978). Cell wall assembly in Bacillus subtilis: location of wall material incorporated during pulsed release of phosphate limitation, its accessibility to bacteriophages and concanavalin $A$, and its susceptibility to turnover. Journal of Bacteriology 136, 886-899.

Blake, C. C. F., Johnson, L. N., Mair, G. A., North, A. C. T., Phillips, D. C. \& SARMA, V. R. (1967). Crystallographic studies of the activity of hen egg-white lysozyme. Proceedings of the Royal Society B167, 378-388.

EDEBO, L. (1961). Lysis of bacteria. 3. On the stability of protoplasts and spheroplasts in different pH-ranges. Acta Pathologica et Microbiologica Scandinavica 53, 121-128.

FermoR, T. R. \& WOOD, D. A. (1981). Degradation of bacteria by Agaricus bisporus and other fungi. Journal of General Microbiology 126, 377-387.

FOUCHE, P. B. \& HASH, J. H. (1978). The $\mathrm{N}, \mathrm{O}$-diacetylmuramidase of Chalaropsis species. Identification of aspartyl and glutamyl residues in the active site. Journal of Biological Chemistry 253, 6787-6793.

GHUYSEN, J.-M., TIPPER, D. J. \& STROMINGER, J. L. (1966). Enzymes that degrade bacterial cell walls. Methods in Enzymology 8, 685-699.

Grant, W. D., Fermor, T. R. \& WoOd, D. A. (1984). Production of bacteriolytic enzymes and degradation of bacterial cell walls during growth of Agaricus bisporus on Bacillus subtilis. Journal of General Microbiology 130, 761-769.

Grant, W. D., Rhodes, L. L., Prosser, B. A. \& Asher, R. A. (1986). Production of bacteriolytic enzymes and degradation of bacteria by filamentous fungi. Journal of General Microbiology 132, 2353-2358.

Grula, E. A. \& HarTSELl, S. E. (1954). Lysozyme action and its relation to the Nakamura effect. Journal of Bacteriology 68, 302-306.

Grula, E. A. \& HARTSELL, S. E. (1957a). Lysozyme in the bacteriolysis of Gram-negative bacteria. I. Morphological changes during use of Nakamura's technique. Canadian Journal of Microbiology 3, 13-22.

Grula, E. A. \& HARTSELL, S. E. (1957b). Lysozyme in the bacteriolysis of Gram-negative bacteria. II. Factors influencing clearing during the Nakamura treatment. Canadian Journal of Microbiology 3, 23-34.

HASH, J. H. (1963). Purification and properties of staphylolytic enzymes from Chalaropsis sp. Archives of Biochemistry and Biophysics 102, 379-388. 
HASH, J. H. (1967). Measurement of bacteriolytic enzymes. Journal of Bacteriology 93, 1201-1202

HaSH, J. H. (1974). Lysozyme Chalaropsis. In Lysozyme, pp. 95-103. Edited by E. F. Osserman, R. E. Canfield \& S. Beychok. New York \& London: Academic Press.

Hash, J. H. \& Rothlauf, M. V. (1967). The $N, O$-diacetylmuramidase of Chalaropsis species. Journal of Biological Chemistry 242, $5586-5590$

Hayashi, K., Kasumi, T., Kubo, N., Sugimoto, T. \& Tsumura, N. (1983). Cultural conditions for lytic enzyme production by Streptomyces rutgersensis. Journal of Fermentation Technology 61, 421-424.

Hayashi, K., Kasumi. T., Kubo, N. \& Tsumura, N. (1984). Properties of $\mathrm{N}$-acetylmuramidase from Streptomyces rutgersensis H-46. Agricultural and Biological Chemistry 48, 465-471

Hughey, V. L. \& JoHnson, E. A. (1987). Antimicrobial activity of lysozyme against bacteria involved in food spoilage and food-borne disease. Applied and Environmental Microbiology 53, 2165-2170.

imada. A., NaKahama, K., Igarasi, S. \& Isono, M. (1973). A bacterioiytic enzyme from Chaetomium globosum, a marine isolate. Archiv für Mikrobiologie 91, 41-54.

van Iterson, W. \& OP DEN Kamp, J. A. F. (1969). Bacteria-shaped gymnoplasts (protoplasts) of Bacillus subtilis. Journal of Bacteriology $99,304-315$

MaRuhn, D., Fuchs, 1., Mues, G. \& Bock, K. D. (1976). Normal limits of urinary excretion of eleven enzymes. Clinical Chemistry 22, $1567-1574$.

Morita, T., Hara, S. \& Matsushima, Y. (1978). Purification and characterization of lysozyme produced by Streptomyces ervthraeus. journal of Biochemistry 83, 898-903.

NaKAMURA, O. (1923). Ueber Lysozymwirkungen. Zeitschrift für Immunitätsforschung und experimentelle Therapie 38, 425-447.

Op den Kamp. J. A. F., van Iterson, W. \& van Deenen, L. L. M. (1967). Studies on the phospholipids and morphology of protoplasts of Bacillus megaterium. Biochimica et Biophysica Acta 135, 862-884.
Paice, M. G., Desrochers, M., Rho, D., Jurasek, L., Roy, C. Rollin, C. F., DE Miguel, E. \& YAGUCHI, M. (1984). Two forms of endoglucanase from the basidiomycete Schizophyllum commune and their relationship to other $\beta$-1,4-glycoside hydrolases. Bio/technology 2, 535-539.

PARK, J. T. \& Johnson, M. J. (1949). A submicrodetermination of glucose. Journal of Biological Chemistry 181, 149-151.

Rupley, J. A., Banerjee, S. K., Kreger, I., Lapanje, S., Shrake, A. F. \& TURK, V. (1974). Structure and chemistry of lysozyme: $\mathrm{pH}$ rate profile, calorimetric studies, and computations on exposure to solvent. In Lysozyme, pp. 251-267. Edited by E. F. Osserman, R. E. Canfield \& S. Beychok. New York \& London: Academic Press.

Seitz, L. M., Sauer, D. B., Burroughs, R., Mohr, H. E. \& Hubbard, J. D. (1979). Ergosterol as a measure of fungal growth. Phytopathology 69, 1201-1203.

Ward, B. J. \& Perkins, H. R. (1968). The purification and properties of two staphylolytic enzymes from Streptomyces griseus. Biochemical Journal 106, 69-76.

Wecke, J., Lahav, M., Ginsburg, I. \& Giesbrecht, P. (1982). Cell wall degradation of Staphylococcus aureus by lysozyme. Archives of Microbiology 131, 116-123.

Yaguchi, M., Roy, C., Rollin, C. F., Paice, M. G. \& Jurasek, L. (1983). A fungal cellulase shows sequence homology with the active site of hen egg-white lysozyme. Biochemical and Biophysical Research Communications 116, 408-411.

Yokogawa, K., Kawata, S. \& Yoshimura, Y. (1973). Lytic enzyme from Streptomyces globisporus 1829 strain. Agricultural and Biological Chemistry 37, 799-808

Yokogawa, K., Kawata, S., Nishimura, S., Ikeda, Y. \& Yoshimura, Y. (1974). Mutanolysin, bacteriolytic agent for cariogenic streptococci: partial purification and properties. Antimicrobial Agents and Chemotherapy 6, 156-165

Yokogawa, K., Kawata, S., Takemura, T. \& Yoshimura, Y. (1975). Purification and properties of lytic enzymes from Streptomyces globisporus 1829. Agricultural and Biological Chemistry 39, 1533-1543. 